Received $7^{\text {th }}$ April 2020

Accepted $2^{\text {nd }}$ August 2020

Link to DOI:

10.25220/WNJ.V04.i1.0008

Journal Website:

www.worldnutrijournal.org

\section{Comparison of short-term memory between stunting and non- stunting children in urban and rural elementary school students in Kupang 2019}

Wahda Dwi Sari ${ }^{1}$, Christina Olly Lada², Rr. Listyawati Nurina ${ }^{3}$, Maria Agnes ED ${ }^{4}$

1. Faculty of Medicine, Nusa Cendana University, Kupang, East Nusa Tenggara, Indonesia

2. Department of Nutrition, Faculty of Medicine, Nusa Cendana University, Kupang, East Nusa Tenggara, Indonesia

3. Department of Farmacology, Faculty of Medicine, Nusa Cendana University, Kupang, East Nusa Tenggara, Indonesia

4. Department of Public Health, Faculty of Medicine, Nusa Cendana University, Kupang, East Nusa Tenggara, Indonesia

\section{Corresponding author:}

Wahda Dwi Sari, MD

Faculty of Medicine, Nusa Cendana University, Kupang, East Nusa Tenggara, Indonesia

Email:wahdasari@gmail.com

\section{Introduction}

Stunting is an impaired growth in children. ${ }^{1}$ Stunting represent a chronic malnutrition, which means the pathological process begins in the womb. ${ }^{2,3}$ Stunting is defined as a short or very short body condition with $\mathrm{z}$-score height-for age below -2 standard 
deviations from the World Health Organization (WHO) child growth standards median. ${ }^{1}$

The highest prevalence of stunting according to WHO, The United Nations Children's Fund (UNICEF) and The World Bank Group are in the developing and third world countries with middle to lower income. ${ }^{4,5}$ In year 2000 , stunted children reached $32.7 \%$ of the child's population in the world. While in 2015 it reached $23.2 \%$ with more than half of the population is in Asia and more than one third in Africa. ${ }^{5}$

In Indonesia, the prevalence of stunted children aged $<5$ years in 2018 was $30.8 \%$ consists of $11.5 \%$ very short and $19.3 \%$ short. $^{6}$ If the nutrition of those stunted children is not improved, it can be continued until school age. ${ }^{7}$ The prevalence of stunting in Indonesia of school age children in 2007 was $36.8 \%$, while in 2013 the prevalence of stunting on children aged 5-12 years was 30.7\% ${ }^{8,9}$ The East Nusa Tenggara province is one of the 15 provinces in Indonesia which has a short and very short prevalence above the national prevalence. ${ }^{8}$

Stunting is influenced by the condition of the first 1000 days of life that starts from conception to the first two years of life and this period is called critical windows, because during this period there is a rapid development of body cells including bone so that if nutritional needs is not fulfilled, it can cause stunting. ${ }^{10}$ Stunting can cause disruption of child's growth and development, intellectual impairment, lower immunity, vurnerable to risk of noncommunicable diseases, decreasing the level of creativity and productivity, increasing the risk of morbidity and mortality. ${ }^{11}$ Stunting describes as a chronic state of malnutrition in which the supply of nutrients needed by the body including the brain is deficient. ${ }^{1,12}$ This causes unoptimal brain development, therefore it can affect the cognitive function of children. ${ }^{13}$

Stunting is related to decreased cognitive abilities in children. Inadequate nutrient intake for a long time will directly affect the development and maturation of brain function. Disruption of brain development and maturation is associated with decreased cognitive abilities. Decreased cognitive abilities will have an impact on children's learning processes. Short-term memory is important for the learning process and the formation of long-term memory. ${ }^{14}$
Short-term memory is the capacity to store a limited amount of information. New information received from the environment will be stored in memory, activated and combined with old memory that has been formed. ${ }^{15}$ Memory describes a person's capacity for learning and is closely related to the role of the hippocampus. ${ }^{16}$ There are various factors that can affect one's memory including: age, stress, sleep, nutrition and physical activity. ${ }^{17}$

The research that was conducted by Horiuchi et $\mathrm{al}^{18}$ in Cambodia in 2018 on the differences of the nutritional status in urban and rural areas of schoolage children found that the children in rural areas had a higher prevalence of stunting than urban areas, this was highly associated with the differences of food intake between the two regions. Another research that was conducted by Addiniya et $\mathrm{al}^{19}$ in 2014 on the comparison of intelligence based on short-term memory tests in urban and rural students in Jatinangor Region using digit span forward, digit span backward and symbol digit modality tests found that the digit span backward and symbol digit modality tests in children in urban areas were scored higher than those children in rural areas. This shows that stunting rates and short-term memory abilities of elementary school students differ between urban and rural areas.

Based on this background, researcher felt the need to conduct a research on the impact of stunting and the short-term memory in urban and rural elementary school students in Kupang of East Nusa Tenggara Province.

\section{Methods}

This research is using analytic observational method with cross sectional design, where the independent variables (stunting and non-stunting) and the dependent variable (short-term memory) are measured at the same time. The instrument that was used to measure the independent variable was the WHO anthroplus, the method of measurement is by measuring the height of the student and assessed the data by WHO anthroplus application. The instrument that was used to measure short-term memory was digit span, the method of this measurement is by mentioning a few numbers and then asking the student to reiterate the figures. The measurements of stunting and short-term memory 
were carried out by researchers. Digit span questionnaire was tested for validation and reliability. Measurements of sleep quality, physical activities, socioeconomic parents, and occupation were collected by a direct interview with questionnaires asked by researchers, since these are some factors that could affects child's short-term memory. Measurement of food intake was measured using a food frequency questionnaire. This research was conducted in two places, Inpres Bertingkat Kelapa Lima 1 elementary school (urban) and Inpres Noelbaki elementary school (rural) from September to October 2019.

The population in this study were elementary school students grades three through five in Inpres Bertingkat Kelapa Lima 1 elementary school and Inpres Noelbaki elementary school with the total number of 452 people. There are 160 elementary school children who met the inclusion criteria that currently on grade 3-5, aged 9-11 years, children were able to hear and talk and willing to be the subject of the research. The exclusion criteria were children who suffer from disability, experiences stress or have a mood feeling questionnaire score (MFQ $>11$ ), history of head trauma, seizures, central nervous system infection, comma, spinal disorders and congenital equinovarus (clubfoot), diarrhea and intestinal worms. The sampling technique in this research used consecutive sampling technique.

This study was analyzed univariately and bivariately. The bivariate analysis $\mathrm{s}$ using Chi Square test with significant $p$ value $\leq 0.05$. This study has been approved by the Research Ethics Committee of the Medical Faculty Nusa Cendana University (Approval Number: 64/UN15.16/KEPK/2019).

\section{Results}

A total of 160 children participated in this study. Table 1 shows the baseline characteristic data of subjects. Table 2, Table 3, and Table 4 shows physical activities, quantity and quality of sleep, parents' income and occupation, respectively. As for food consumption patterns, it is shown in Table 5.

Table.6 shows the univariate analysis results of stunting and non-stunting children, based on WHO child growth chart for height-for-age. Comparison of short-term memory between stunting and nonstunting group of children is shown in Table 7.

\section{Discussion}

This study found that (1) the variation of food from the daily intake of the subjects in urban and rural areas is still low. According to UNICEF and WHO the variation of food for children should be at least consist of 4-5 kind of foods. ${ }^{20}$ The results from Food Frequency Questionnaire (FFQ) shows that subjects only consumed 2-3 food ingredients each day. (2) There was an inadequate sources of omega 3 food such as salmon, mackerel, catfish, sardines, shrimp, squid, fish oil and nuts. Omega 3 plays an important role in morphological, biochemical and molecular development of the brain, so that if the daily intake of omega 3 is insufficient, it will reduce the intelligence of children that can be seen by their low short-term memory. ${ }^{21}$ Based on FFQ results, the daily consumption of fish which is a source of omega 3 in urban and rural areas were still relatively low.

Bone growth in school-aged children is influenced by food intake, if the child's food intake is inadequate, the bone growth will be disturbed and the child will be stunted. Food ingredients that contain nutrients for bone growth are protein, calcium, phosphorus, vitamins, magnesium and zinc. $^{22-24}$ Protein is important to form new bone tissues and replace the damaged bone tissue. Protein sources are divided into 2 types, (1) animals-source such as beef, chicken, eggs, and fish and (2) vegetables-source such as tofu, tempeh and beans. ${ }^{22}$ Based on the results of FFQ, subjects in rural areas often consume animal protein i.e. fish and subjects in urban areas often consume vegetable source protein such as tofu and tempeh. The essential role of calcium is to form bones and teeth, the main source of calcium comes from milk. ${ }^{24}$ Based on FFQ results, daily milk consumption in urban areas was higher than in rural areas.

Phosphorus plays a role in bone and tooth mineralization. Food sources that contain phosphor are tofu, spinach and cassava leaves. ${ }^{23}$ Based on the results of the FFQ, the daily consumption of tofu in urban areas and in rural areas was still relatively low. Vitamins that play a role in helping bone growth are vitamin $\mathrm{A}$ and vitamin $\mathrm{C}$. Vitamin A plays an 
essential role for bone development, while vitamin $\mathrm{C}$ is optimizing the absorption of calcium which can affect the bone growth. Food which contain lots of vitamin $\mathrm{A}$ are carrots while lots of vitamin $\mathrm{C}$ can be found in oranges. ${ }^{24}$ Based on FFQ results, the daily consumption of carrots and oranges is still low.

Magnesium and zinc have the same function as phosphor in the role of mineralization of bones and teeth. ${ }^{22,24}$ Food sources that contain lots of magnesium are green vegetables. ${ }^{24}$ Food sources that contain zinc are animal protein. ${ }^{22}$ Green vegetables that are included in the FFQ questionnaire were cassava leaves, spinach and kale. It was found that there are 93 subjects who consumed kale based on the results of FFQ in urban and rural areas. From the discussion above, it can be concluded that the daily consumption of the subject's nutrients to meet the ideal needs of bone growth is still relatively low.

The results found that there is no significant difference in short-term memory between stunting and non stunting in elementary school students, these results are same with the research conducted by Sadikin ${ }^{14}$ in Indonesia, especially in Jatinangor Region in 2015 about the comparison of short-term memory in 60 elementary students grade 3-5 who were stunting and not stunting, it was found that there was no significant difference in short-term memory between stunting and non-stunting students. ${ }^{14}$ Table 7 shows the pattern of how stunting subjects tend to have relatively low short-term memory. The table also shows that the total of stunting subjects in urban areas was $25 \%$ with low short-term memory, while in rural areas $46.2 \%$ of stunting subjects had low short-term memory. This shows that the percentage of stunting subjects in rural areas who has short-term memory is lower by $21 \%$ compared to stunting subjects in urban areas.

Low short-term memory in rural subjects may be influenced by internal and external factors. Internal factors include the quality and quantity of nutrient intake, sleep quality and physical activities. ${ }^{17,25}$ While the external factors are stimulation or training. ${ }^{26}$ Based on the distribution of the data it can be seen that the daily consumption of fish in rural areas was higher than in urban areas. However, not all subjects in rural areas consume fish every day. Fish is a source of omega 3, where omega 3 plays a role in increasing the intelligence, if the consumption of omega 3 is inadequate then the intelligence will also be impaired..$^{21}$ The quality of sleep on subjects in rural areas was better than in urban areas, which means that the corellation of lowterm memory with low-quality of sleep can be removed. Physical activity of subjects in rural were higher regularity and frequency compared to urban areas. Regular physical activities often has positive impact on short-term memory but it must be followed by adequate food consumption to optimize the subject's short-term memory. ${ }^{17}$ External factors such as stimulation / repetitive exercise will improve the ability of short-term memory of the subject. ${ }^{27}$

A research conducted by Sadikin was also supported by the research conducted by Sokolovic et $\mathrm{al}^{28}$ in India of 1040 elementary school students who were stunted after a nutritional intervention for six months found that the short-term memory abilities, retrieval abilities, and visuospatial abilities were not significantly different before and after the intervention with the $\mathrm{p}$ value $>0.1$.

In contrast to the results of the research conducted by Woldehanna et $\mathrm{al}^{13}$ in 2017 in children aged 5-8 years with a total sample of 2000 children in Ethiopia was found that the stunted children had lower cognitive abilities (which can also be described by short-term memory function) with a significance value of $\mathrm{p}<0.01$ compared with children who are not stunting.

Some studies suggest that the hippocampus is assumed to have a crucial role in determining the power of the brain in capturing and storing the memory. This adequate nutrition early in life will affect the hippocampus. Based on these findings, height-for-age correlates with inadequate nutrition at the beginning of growth because height reflects the nutritional status in the past. ${ }^{16,29}$

Short-term memory is the capacity to store a limited amount of information. Low short-term memory in children will affect the learning process of children in school, children who have low shortterm memory must be given a stimulus repeatedly so that the new information obtained can be stored in their memory. ${ }^{27}$ The ability that can be disrupted in children who have low short-term memory is the ability to read and write, while in elementary school children this ability is taught as the basis of their knowledge which will be applied to further 
education. If the ability to read and write is disrupted it will have an adverse effect during adult. ${ }^{30}$

The results of this study indicate that stunting and non-stunting children don't have significant differences in cognitive abilities, especially in shortterm memory. This is caused by various factors such as parental education, socioeconomic and environment. ${ }^{31}$ Parental education background was not examined by the researcher. However, the socioeconomics factors obtained in the characteristics is that the majority of parents have a low income $<1$ million rupiah which illustrates that most of the subjects has a low economy capacity, this could affect their food availability in household which then resulted in low nutritional intake of the subject. ${ }^{32}$ The intake of omega 3 nutrients that affect the short-term memory in stunting and non-stunting children was still very low. So there was no significant difference between stunting and nonstunting children. For the occupational factors, the majority of subject's father worked as a farmer and the mother as a housewife. Having most of the subject's mothers as a housewives is a positive thing because mothers have enough time for parenting, rising, and caring for their children. Parental genetic factors can also contribute to cognitive development. In general, these factors will affect the child's growth and development process. However, it depends on different stimulations and responses that can affect the child's growth and development process. $^{31}$

\section{Conclusions}

Based on the results of the study it can be concluded that there is no significant differences in short-term memory between stunting and non stunting in elementary school children, both in urban and rural areas of Kupang, but in rural elementary schools the prevalence of subjects in stunting group with shortterm memory abilities is relatively low, $21.2 \%$ higher compared to urban elementary schools.

Table 1. Baseline characteristics of subjects $(n=160)$

\begin{tabular}{cc}
\hline \multicolumn{1}{c}{ Characteristics } & $\mathrm{n}(\%)$ \\
\hline Age (years) & $85(53.1)$ \\
9 & $59(36.9)$ \\
10 & $16(10.0)$ \\
11 & \\
Elementary school grade & $18(11.3)$ \\
3 & $81(50.6)$ \\
4 & $61(38.1)$ \\
5 & \\
Fender & $80(50)$ \\
Erban & $44(55)$ \\
Rural & $36(45)$ \\
Male & $80(50)$ \\
Urban & $36(45)$ \\
Rural & $44(55)$ \\
\hline
\end{tabular}


Table 2. Characteristics of subjects based on physical activity

\begin{tabular}{|c|c|c|}
\hline & Physical activity & $\mathrm{n}(\%)$ \\
\hline \multicolumn{3}{|l|}{ Type of activity } \\
\hline \multirow[t]{3}{*}{ Light } & & $36(22.5)$ \\
\hline & Urban & $21(26.3)$ \\
\hline & Rural & $15(18.8)$ \\
\hline \multirow[t]{3}{*}{ Moderate } & & $109(68.1)$ \\
\hline & Urban & $46(57.5)$ \\
\hline & Rural & $63(78.8)$ \\
\hline \multirow{3}{*}{ Heavy } & & $15(9.4)$ \\
\hline & Urban & $13(16.3)$ \\
\hline & Rural & $2(2.5)$ \\
\hline \multicolumn{3}{|l|}{ Constancy } \\
\hline \multirow[t]{3}{*}{ Irregular } & & $47(29.4)$ \\
\hline & Urban & $25(53.2)$ \\
\hline & Rural & $22(46.8)$ \\
\hline \multirow[t]{3}{*}{ Regular } & & $113(70.6)$ \\
\hline & Urban & $55(48.7)$ \\
\hline & Rural & $58(51.3)$ \\
\hline \multicolumn{3}{|l|}{ Frequency } \\
\hline \multirow[t]{3}{*}{$<3 \mathrm{x} /$ week } & & $75(46.9)$ \\
\hline & Urban & $41(54.7)$ \\
\hline & Rural & $34(45.3)$ \\
\hline \multirow[t]{3}{*}{$\geq 3 \mathrm{x} /$ week } & & $85(53.1)$ \\
\hline & Urban & $39(45.9)$ \\
\hline & Rural & $46(54.1)$ \\
\hline
\end{tabular}

Table 3. Quantity and quality of sleep of subjects

\begin{tabular}{|c|c|}
\hline Quantity and quality of sleep & Persentage $(\%)$ \\
\hline \multicolumn{2}{|l|}{ Lenght of sleep: } \\
\hline$<9$ hours & $46(28.8)$ \\
\hline Urban & $29(63)$ \\
\hline Rural & $17(37)$ \\
\hline$\geq 9$ hours & $114(71.3)$ \\
\hline Urban & $51(44.7)$ \\
\hline Rural & $63(55.3)$ \\
\hline \multicolumn{2}{|l|}{ Nap: } \\
\hline Yes & $69(43.1)$ \\
\hline Urban & $43(62.3)$ \\
\hline Rural & $26(37.7)$ \\
\hline No & $91(56.9)$ \\
\hline Urban & $37(40.7)$ \\
\hline Rural & $54(59.3)$ \\
\hline \multicolumn{2}{|l|}{ Often wake up in the middle of the night } \\
\hline Yes & $74(46.3)$ \\
\hline Urban & $47(63.5)$ \\
\hline Rural & $27(36.5)$ \\
\hline No & $86(53.8)$ \\
\hline Urban & $33(38.3)$ \\
\hline Rural & $53(61.7)$ \\
\hline
\end{tabular}


Table 4. Parents' income and occupation

\section{Socioeconomics conditions}

$\mathrm{n}(\%)$

Parents income :

$<1$ million rupiah/month

93(58.1)

1-5 million rupiah/month

57(35.6)

$>5$ million rupiah/month

Father's occupation

Entrepreneur

Government employee

Farmer

$40(25.0)$

Laborer

17(10.6)

Teacher

Seller

Doesn't work

Other

Mother's Occupation

Entrepreneur

Government employee

Farmer

Teacher

Seller

Housewife

109(68.1)

Other

$8(5.0)$

Table 5. Food consumption patterns

\begin{tabular}{|c|c|c|c|c|c|c|c|c|c|c|c|c|}
\hline \multirow{3}{*}{ Food Material } & \multicolumn{10}{|c|}{ Frequency } & \multirow{2}{*}{\multicolumn{2}{|c|}{ Total }} \\
\hline & \multicolumn{2}{|c|}{$>3 x /$ day } & \multicolumn{2}{|c|}{$\leq 3 \mathrm{x} /$ day } & \multicolumn{2}{|c|}{$>3 x /$ week } & \multicolumn{2}{|c|}{$\leq 3 \mathrm{x} /$ week } & \multicolumn{2}{|c|}{ Never } & & \\
\hline & $\mathrm{n}$ & $\%$ & $\mathrm{n}$ & $\%$ & $\mathrm{n}$ & $\%$ & $\mathrm{n}$ & $\%$ & $\mathrm{n}$ & $\%$ & $\mathrm{n}$ & $\%$ \\
\hline \multicolumn{13}{|c|}{ Staple Food } \\
\hline Rice & 32 & 20 & 124 & 77.5 & 4 & 2,5 & 0 & 0 & 0 & 0 & 160 & 100 \\
\hline Noodles & 4 & 2.5 & 27 & 16.9 & 20 & 12.5 & 98 & 61.3 & 11 & 6.9 & 160 & 100 \\
\hline Bread & 10 & 6.3 & 51 & 31.9 & 16 & 10 & 73 & 45.6 & 10 & 6.3 & 160 & 100 \\
\hline \multicolumn{13}{|c|}{ Side Dishes } \\
\hline Wet Fish & 7 & 4.4 & 36 & 22.5 & 10 & 6.3 & 80 & 50 & 27 & 16.9 & 160 & 100 \\
\hline Dried Fish & 7 & 4.4 & 46 & 28.8 & 13 & 8.1 & 78 & 48.8 & 16 & 10 & 160 & 100 \\
\hline Egg & 8 & 5 & 49 & 30.6 & 16 & 10 & 81 & 50.6 & 6 & 3.8 & 160 & 100 \\
\hline Chicken Meat & 6 & 3.8 & 17 & 10.6 & 16 & 10 & 107 & 66.9 & 14 & 8.8 & 160 & 100 \\
\hline Meat & 2 & 1.3 & 15 & 9.4 & 15 & 9.4 & 106 & 66.3 & 22 & 13.8 & 160 & 100 \\
\hline Tofu & 13 & 8.1 & 61 & 38.1 & 14 & 8.8 & 63 & 39.4 & 9 & 5.6 & 160 & 100 \\
\hline Tempeh & 13 & 8.1 & 62 & 38.8 & 17 & 10.6 & 62 & 38.8 & 6 & 3.8 & 160 & 100 \\
\hline \multicolumn{13}{|c|}{ Vegetables } \\
\hline Cassava Leaves & 5 & 3.1 & 13 & 8.1 & 8 & 5 & 81 & 50.6 & 53 & 33.1 & 160 & 100 \\
\hline Spinach & 6 & 3.8 & 36 & 22.5 & 11 & 6.9 & 75 & 46.9 & 32 & 20 & 160 & 100 \\
\hline Kale & 7 & 4.4 & 86 & 53.8 & 13 & 8.1 & 47 & 29.4 & 7 & 4.4 & 160 & 100 \\
\hline Carrot & 6 & 3.8 & 26 & 16.3 & 14 & 8.8 & 74 & 46.3 & 40 & 25 & 160 & 100 \\
\hline Cabbage & 8 & 5 & 23 & 14.4 & 8 & 5 & 72 & 45 & 49 & 30.6 & 160 & 100 \\
\hline Cauliflower & 3 & 1.9 & 10 & 6.3 & 7 & 4.4 & 63 & 39.4 & 77 & 48.1 & 160 & 100 \\
\hline Mustard Greens & 7 & 4.4 & 40 & 25 & 10 & 6.3 & 60 & 37.5 & 43 & 26.9 & 160 & 100 \\
\hline Long beans & 4 & 2.5 & 17 & 10.6 & 13 & 8.1 & 75 & 46.9 & 51 & 31.9 & 160 & 100 \\
\hline
\end{tabular}


Table 5. Food consumption patterns (continued)

\begin{tabular}{|c|c|c|c|c|c|c|c|c|c|c|c|c|}
\hline \multirow{3}{*}{ Food Material } & \multicolumn{10}{|c|}{ Frequency } & \multirow{2}{*}{\multicolumn{2}{|c|}{ Total }} \\
\hline & \multicolumn{2}{|c|}{$>3 x /$ day } & \multicolumn{2}{|c|}{$\leq 3 \mathrm{x} /$ day } & \multicolumn{2}{|c|}{$>3 \mathrm{x} /$ week } & \multicolumn{2}{|c|}{$\leq 3 \mathrm{x} /$ week } & \multicolumn{2}{|c|}{ Never } & & \\
\hline & $\mathrm{n}$ & $\%$ & $\mathrm{n}$ & $\%$ & $\mathrm{n}$ & $\%$ & $\mathrm{n}$ & $\%$ & $\mathrm{n}$ & $\%$ & $\mathrm{n}$ & $\%$ \\
\hline \multicolumn{13}{|c|}{ Fruits } \\
\hline Banana & 11 & 6.9 & 49 & 30.6 & 12 & 7.5 & 80 & 50 & 8 & 5 & 160 & 100 \\
\hline Orange & 1 & 0.6 & 23 & 14.4 & 12 & 7.5 & 99 & 61.9 & 25 & 15.6 & 160 & 100 \\
\hline Watermelon & 3 & 1.9 & 25 & 15.6 & 12 & 7.5 & 96 & 60 & 24 & 15 & 160 & 100 \\
\hline Papaya & 7 & 4.4 & 41 & 25.6 & 5 & 3.1 & 85 & 53.1 & 22 & 13.8 & 160 & 100 \\
\hline Pineapple & 0 & 0 & 8 & 5 & 5 & 3.1 & 61 & 38.1 & 86 & 53.8 & 160 & 100 \\
\hline Mango & 5 & 3.1 & 104 & 65 & 15 & 9.4 & 29 & 18.1 & 7 & 4.4 & 160 & 100 \\
\hline \multicolumn{13}{|c|}{ Drink } \\
\hline Tea & 10 & 6.3 & 73 & 45.6 & 12 & 7.5 & 36 & 22.5 & 29 & 18.1 & 160 & 100 \\
\hline Coffee & 0 & 0 & 17 & 10.6 & 5 & 3.1 & 43 & 26.9 & 95 & 59.4 & 160 & 100 \\
\hline Milk & 11 & 6.9 & 67 & 41.9 & 13 & 8.1 & 48 & 30 & 21 & 13.1 & 160 & 100 \\
\hline
\end{tabular}

Table 6. Univariate analysis of subject according to WHO growth chart for height-for-age

\begin{tabular}{lcc}
\hline & Height-for-age & $\mathrm{n}(\%)$ \\
\hline Stunting & $52(32.5)$ \\
Non stunting & $108(67.5)$ \\
\hline
\end{tabular}

Table 7. Comparison of short term memory between stunting and non-stunting group

\begin{tabular}{|c|c|c|c|}
\hline \multirow[b]{2}{*}{ Height-for-age } & \multicolumn{2}{|c|}{ Short term memory } & \multirow[b]{2}{*}{ p value* } \\
\hline & $\begin{array}{l}\text { Low } \\
\mathrm{n}(\%)\end{array}$ & $\begin{array}{c}\text { Moderate } \\
\mathrm{n}(\%)\end{array}$ & \\
\hline \multicolumn{4}{|l|}{ Stunting } \\
\hline Urban & $13(25)$ & $8(15.4)$ & \multirow{5}{*}{0.144} \\
\hline Rural & $24(46.2)$ & $7(13.4)$ & \\
\hline Non stunting & & & \\
\hline Urban & $32(29.6)$ & $27(25)$ & \\
\hline Rural & $32(29.6)$ & $17(15.8)$ & \\
\hline
\end{tabular}




\section{Conflict of Interest}

Authors declared no conflict of interest regarding this article.

\section{Open Access}

This article is distributed under the terms of the Creative Commons Attribution 4.0 International Licence (http://creativecommons.org/licenses/by/4.0/), which permits unrestricted use, distribution, and reproduction in any medium, provided you give appropriate credit to the original author(s) and the source, provide a link to the Creative Commons license, and indicate if changes were made.

\section{References}

1. Atmarita, Zahrani Y, Akim D. Situasi Balita Pendek (Stunting) di Indonesia. Buletin Jendela Data dan Informasi Kesehatan. 2018;2.

2. Sandjojo EP. Buku Saku Desa dalam Penanganan Stunting. Kementerian Desa, Pembangunan Daerah Tertinggal, dan Transmigrasi. 2017;4.

3. Victora CG, Adair L, Fall C, Hallal PC, Martorell $\mathrm{R}$, Richter $\mathrm{L}$, et al. Maternal and child undernutrition : consequences for adult health and human capital. Matern Child Undernutrition 2. 2008;371:340-57.

4. Latif RV, Istiqomah N. Determinan stunting pada siswa SD di kabupaten pekalongan. Unnes $J$ Public Heal. 2017;6(3):69-71.

5. UNICEF, WHO, Group WB. Levels And Trends In Child Malnutrition. Child Malnutrition Estimates. 2016;1-8.

6. Kemenkes. Riset Kesehatan Dasar. Badan Penelitian dan Pengembangan Kesehatan; 2018 p. 11.

7. Tando NM. Durasi dan Frekuensi Sakit Balita dengan Terjadinya Stunting Pada Anak SD di Kecamatan Malalayang Kota Manado. Gizido. 2012;4(1):338-40.

8. Kemenkes. Riset Kesehatan Dasar. Badan Peneletian dan Pengembangan Kesehatan; 2013 p. 216-8.

9. Rochimiwati SN, Rowa SS, Aprilia I. Stunting dan Prestasi Belajar Anak Sekolah Dasar. Media Gizi Pangan. 2016;XXII:11-3.

10. Nutrition in the First 1,000 Days State of the World's Mothers 2012. Johnson \& Johnson, Mattel, Inc. and Brookstone; 2012. 5 p.
11. Khoirun N, Nadhiroh SR. Faktor yang berhubungan dengan kejadian stunting pada balita. Media Gizi. 2015;10:13-9.

12. Kemenkeu. Penanganan Stunting Terpadu Tahun 2018. Jakarta: Direktur Anggaran Bidang Pembangunan Manusia dan Kebudayaan; 2018. p. 4.

13. Woldehanna T, Behrman JR, Araya MW. The effect of early childhood stunting on children's cognitive achievements: Evidence from young lives Ethiopia. HHS Public Access. 2018;31(2):75-84.

14. Sadikin IS, Lubis L, Djais JTB. Short-term Memory Comparison between Stunted and NonStunted Groups. Althea Med J. 2018;5(3):111-5.

15. May CP, Einstein GO, Freedman S. A Five-Day Unit Lesson Plan for High School Psychology Teachers. Memory. 2013;6-7.

16. Guigon E, Burnod Y, Creare I. Short-term memory Short-Term Memory at the Neural Level. 1995. 867-871 p.

17. Amin HU, Malik A. Memory Retention and Recall Process. In 2014. p. 232.

18. Horiuchi Y, Kusama K, Kanha S, Yoshiike N. Urban-Rural Differences in Nutritional Status and Dietary Intakes of School-Aged Children in Cambodia. Nutrients. 2018;11(14):1-13.

19. Addiniya A, Lubis L, Prananta MS. Comparison of Intelligence based on Short-term Memory Test between Urban and Rural Children. Althea Medical Journal. 2019;6(3):123-8.

20. Diana FM. Omega 3. J Kesehat Masy. 2012;6(2):113-7.

21. Fandakova $\mathrm{Y}$, Sander MC, Werkle-bergner M, Shing YL. Age Differences in Short-Term Memory Binding Are Related to Working Memory Performance Across the Lifespan. Psychol abd Aging. 2014;29(April 2015):140-7.

22. Greatalya LAD. Omega 3 dalam Ikan Sarden Sebagai Penambah Daya Ingat. Skripsi Univ Sebel Maret. 2008;1-5.

23. Nurasmi, Sari AP, Rusmiati. Analisis Kandungan Asam Lemak Omega 3, Omega 6 Dan Omega 9 Dari Ikan Lele (Clarias sp) Pada Peningkatan Nutrisi Balita. 2018. p. 1-4.

24. UNICEF. Children, food and nutrition. Keeley B, Little C, Zuehlke E, editors. 2019. 74-75 p.

25. Li D. A Study On The Relationship Between Sleep Quality And Some Psychological Function Of College Students. Acta Psycholoogical Sin. 1985;17(4):82-6.

26. Bhinnety M. Struktur dan Proses Memori. Buletin Psikologi. 16(2):74-88. 
27. Pratiwi O. Pengaruh Kebiasaan Konsumsi Energi, Protein, Dan Seng Terhadap Kejadian Stunting Pada Anak Usia Sekolah Dasar Di Kecamatan Salapian Kabupaten Langkat Tahun 2017. Repos Institusi USU. 2017;2(2):8-15.

28. Sokolovic N, Selvam S, Srinivasan K, Thankachan P, Kurpad A V, Thomas T. Catch-up growth does not associate with cognitive development in Indian school-age children. Eur $J$ Clin Nutr [Internet]. 2013;68(1):14-8. Available from: http://dx.doi.org/10.1038/ejen.2013.208

29. Monti JM, Baym CL, Cohen NJ. Identifying and Characterizing the Effects of Nutrition on
Hippocampal Memory 1-3. Supplement. 2014;5:337-43.

30. Almatsier S. Prinsip Dasar Ilmu Gizi. Jakarta: Gramedia Pustaka Utama; 2010. 157-165 p.

31. Souza AS De, Fernandes FS, Tavares G. Effects of maternal malnutrition and postnatal nutritional rehabilitation on brain fatty acids, learning, and memory. Nutr Rev. 2011;69(3):132-44.

32. Putranto PL. The Effect of Brain Gym to the Short Term Memory Function of Program Pascasarjana Magister Ilmu Biomedik Program Pendidikan Dokter Spesialis I. Universitas Diponegoro; 2009. 